\title{
Develop Attitude Scale and Measure the Attitude of Farmers towards Recommended Soybean Cultivation Practices
}

\author{
Surendra Kumar*, N.K. Sharma, H.S. Bunkar and Ramdhan Gashwa \\ Department of Extension Education, SKN College of Agriculture, Jobner, \\ Jaipur-303 329, India \\ *Corresponding author
}

\begin{tabular}{|l|}
\hline Ke y w o r d s \\
$\begin{array}{l}\text { Level of attitude, Mean } \\
\text { Per cent Score and } \\
\text { recommended soybean } \\
\text { cultivation practices }\end{array}$ \\
\hline Article Info \\
\hline $\begin{array}{l}\text { Accepted: } \\
\text { 28 February } 2018 \\
\text { Available Online: } \\
\text { 10 March } 2018\end{array}$ \\
\hline
\end{tabular}

\section{Introduction}

Soybean [Glycine max (L.) Marril] belongs to family leguminoceae, sub family papilionaceae and genus glycine. It is mainly grown in kharif season. Soybean is reported to have originated in eastern Asia or China and has been to man over 5000 years. It was introduced in USA in the year 1804 and has since revolutionized the agriculture of that country. In India efforts have been made since 1969 to popularize its cultivation and
The present investigation was conducted in Kota region of Rajasthan purposively because this region stands first in area 822329 hectare and production 1197758 tonnes of soybean cultivation among all ten agriculture regions of Rajasthan. Kota region comprises four districts viz., Kota, Baran, Bundi and Jhalawar. Out of these two districts viz., Kota and Jhalawar were selected purposively for this study because of highest area and production. Kota and Jhalawar districts comprise five and seven tehsils, respectively. Out of which two tehsil from Kota (Degod and Ramganj Mandi) and two tehsil from Jhalawar (Khanpur and Manohar Thana) (as per the data of 2014-15) district was selected randomly. Out of these 6 villages were selected from each selected tehsil on the basis of random sampling method. Thus, the total 24 villages were selected. List of all the soybean cultivators was prepared from each of the selected village, with the help of patwari and agriculture supervisor, eight to twelve farmers were selected by using proportionate random sampling technique as per availability so as to make the sample size 220 . It was found that the majority of the farmers (110) were found to have favourable attitude (61.77 per cent) towards recommended soybean cultivation practices whereas 11.57 and 26.66 per cent of farmers were having most favourable and least favourable attitude, respectively. To develop attitude scale and measure the attitude of farmers towards recommended Soybean cultivation practices. consumption. Soybean has been known by various names in India such as Bhat, Bhatman, Ramkuithi etc. It is called the miracle crop of the twentieth century and is popularly known as "queen of pulses," wonder crop, farmer's friend and agriculture's Cinderella.

It is the cheapest source of high quality protein. It contains 20 per cent oil and 40 per cent high quality protein. Its oil is used for manufacturing vanaspati ghee and several other industrial products. 


\section{Materials and Methods}

The present investigation was conducted in Kota region of Rajasthan purposively because this region stands first in area 822329 hectare and production 1197758 tonnes of soybean cultivation among all ten agriculture regions of Rajasthan. Kota region comprises four districts viz., Kota, Baran, Bundi and Jhalawar. Out of these two districts viz., Kota and Jhalawar were selected purposively for this study because of highest area and production. Kota and Jhalawar districts comprise five and seven tehsils, respectively.

Out of which two tehsil from Kota (Degod and Ramganj Mandi) and two tehsil from Jhalawar (Khanpur and Manohar Thana) (as per the data of 2014-15) district was selected randomly. Out of these 6 villages were selected from each selected tehsil on the basis of random sampling method. Thus, the total 24 villages were selected. List of all the soybean cultivators was prepared from each of the selected village, with the help of patwari and agriculture supervisor, eight to twelve farmers were selected by using proportionate random sampling technique as per availability so as to make the sample size 220 .

\section{Measurement of attitude of farmers toward recommended soybean cultivation practices}

To measure the attitude of farmers towards recommended soybean cultivation practices, attitude scale using Likert's technique of summated rating was constructed (AppendixIII). The scale consisted of 18 items, out of which 9 were positive and 9 were negative. The responses obtained were assigned scores as $5,4,3,2$ and 1 to strongly agree, agree undecided, disagree and strongly disagree in case of positive statements. However, for negative items, pattern of scoring was reversed. Total score obtained by each farmer was calculated the respondents were divided into three categories (least favourable, favourable and most favourable) on the basis of mean and standard deviation of their attitude scores as shown under:

Least favourable - < mean - standard deviation)

favourable - mean + standard deviation to mean - standard deviation.

Most favourable - > mean + standard deviation.

Frequency and percentage of respondents in each category were calculated further, per cent level of agreement for each statement was calculated. Also, to find out the significance of difference in attitude between different categories of farmers, and conclusions were drawn accordingly.

\section{Results and Discussion}

\section{Measurement of attitude of farmers towards recommended soybean cultivation practices}

This section of the investigation aims at studying the attitude of the farmers towards recommended soybean cultivation practices. For this, an attitude scale was developed by investigator to measure the attitude of farmers towards recommended soybean cultivation practices to get an overview of the farmers regarding their attitude towards recommended soybean cultivation practices, they were classified into three categories i.e. (i) Least favourable (ii) Favourable and (iii) Most favourable on the basis of calculated mean $(61.52)+$ standard deviation (4.00) obtained by them which are as follows:-

Respondents who scored below 57.52 (Mean standard deviation) were grouped under least favourable attitude. 
The respondents who scored 57.53 to 65.52 (Mean - standard deviation to Mean + standard deviation) were considered under favourable attitude.

Those respondents who obtained score above 65.52 (Mean + standard deviation) were categorized under most favourable attitude.

The statistical data regarding the attitude level of farmers were presented in the Table 1.

The data given in Table 1 reveal that the majority of farmers (110) were found to have favourable attitude (61.77 per cent) towards recommended soybean cultivation practices whereas 11.57 and 26.66 per cent of farmers were having most favourable and least favourable attitude, respectively.

These findings confirm the findings of Kumawat (2015) who revealed that the majority of farmers (84) were found to have favourable attitude (64.61 per cent) towards recommended production technology of rapeseed and mustard crop whereas 18.47 and 16.92 per cent of farmers were having most favourable and least favourable attitude, respectively.

The favourable results regarding attitude of farmers towards recommended soybean cultivation practices were also presented diagrammatically.
Statement wise attitude of farmers towards recommended soybean cultivation practices were also analyzed separately. The relative importance of all the 18 statements related to recommended soybean cultivation practices were highlighted by ranking them on the basis of mean per cent score (MPS) of statements score. The data have been presented in Table 1.

\section{Statement wise attitude of farmers towards recommended soybean cultivation practices}

The statement wise attitude of farmers towards recommended soybean cultivation practices as measured on five point continuum scale has been presented in Table 2 .

The data given in Table 2 indicate that respondents possessed most favourable attitude regarding "I prefer HYVs to local variety as it gives high production than local variety", which secured highest mean per cent score (90.09 MPS), hence this statement was ranked first. The second highest mean per cent score (88.81 MPS) secured by the statement "Recommended field preparation increases production and reduces cost of cultivation", which was ranked second followed by "Application of sulphur increases yield and oil content in soybean seeds", "The soybean cultivation practices have improved social status of the farmers" (85.63 MPS), and (83.54 MPS) ranked third and fourth, respectively.

Table.1 Attitude levels of farmers towards recommended soybean cultivation practices

$\mathrm{N}=220$

\begin{tabular}{|l|l|c|c|}
\hline & Attitude level & Frequency & Percentage \\
\hline 1. & Least favourable (score below 57.52) & 71 & 26.66 \\
\hline 2. & Favourable (score from 57.53 to 65.52) & 110 & 61.77 \\
\hline $3 . \quad$ Most favourable(score above 65.52) & 39 & 11.57 \\
\hline & Total & 220 & 100.00 \\
\hline $\bar{X}=61.52$ & $\sigma=4.00$ & & \\
\hline
\end{tabular}


Table.2 Statement wise attitude of farmers towards recommended soybean cultivation practices

$\mathrm{N}=220$

\begin{tabular}{|c|c|c|c|c|c|c|c|c|c|}
\hline \multirow[t]{2}{*}{ S. No. } & \multirow[t]{2}{*}{ Aspects } & \multirow{2}{*}{$\begin{array}{l}\text { "t" value } \\
\text { (Critical } \\
\text { ratio } \\
\text { value) }\end{array}$} & \multicolumn{7}{|c|}{ Number of farmers } \\
\hline & & & SA & $\mathbf{A}$ & UD & DA & SDA & MPS & Rank \\
\hline 1. & $\begin{array}{l}\text { I prefer HYVs to local } \\
\text { variety as it gives high } \\
\text { production than local variety } \\
(+)\end{array}$ & 4.44 & 140 & 67 & 0 & 10 & 3 & 90.09 & I \\
\hline 2. & $\begin{array}{l}\text { Recommended Soybean } \\
\text { cultivation practices are not } \\
\text { suitable for uneducated } \\
\text { farmers (-) }\end{array}$ & 1.98 & 58 & 63 & 9 & 34 & 56 & 57.00 & XVII \\
\hline 3. & $\begin{array}{l}\text { Recommended Soybean } \\
\text { cultivation practices require } \\
\text { regular contact with } \\
\text { extension Workers }(+)\end{array}$ & 3.02 & 79 & 108 & 8 & 25 & 0 & 81.54 & VII \\
\hline 4. & $\begin{array}{l}\text { HYVs are more expensive } \\
\text { than local variety as they } \\
\text { have higher seed cost }(-)\end{array}$ & 1.84 & 51 & 69 & 2 & 17 & 81 & 60.72 & XVI \\
\hline 5. & $\begin{array}{l}\text { HYVs have good storage } \\
\text { quality so can be stored for a } \\
\text { longer period of time }(+)\end{array}$ & 3.10 & 97 & 79 & 30 & 14 & 0 & 82.45 & V \\
\hline 6. & $\begin{array}{l}\text { I have not preferred } \\
\text { recommended dose of NPK } \\
\text { and pesticides (-) }\end{array}$ & 4.34 & 11 & 26 & 21 & 90 & 72 & 76.90 & XII \\
\hline 7. & $\begin{array}{l}\text { The Soybean cultivation } \\
\text { practices have improved } \\
\text { social status of the farmers } \\
(+)\end{array}$ & 2.20 & 90 & 112 & 0 & 18 & 0 & 83.54 & IV \\
\hline 8. & $\begin{array}{l}\text { Soil testing is not necessary } \\
\text { for application of } \\
\text { recommended quantity of } \\
\text { chemical fertilizers (-) }\end{array}$ & 4.10 & 91 & 30 & 19 & 29 & 51 & 53.00 & XVIII \\
\hline 9. & $\begin{array}{l}\text { Recommended Soybean } \\
\text { cultivation practices are } \\
\text { cheap, and trust worthy }(+)\end{array}$ & 1.88 & 69 & 101 & 40 & 10 & 0 & 80.63 & VIII \\
\hline 10. & $\begin{array}{l}\text { Technology advocated is not } \\
\text { according to farmers' } \\
\text { resources and their needs (-) }\end{array}$ & 4.46 & 9 & 33 & 24 & 90 & 64 & 75.18 & XIII \\
\hline 11. & $\begin{array}{l}\text { Recommended field } \\
\text { preparation increases } \\
\text { production and reduces cost } \\
\text { of cultivation }(+)\end{array}$ & 4.02 & 103 & 117 & 0 & 0 & 0 & 88.81 & II \\
\hline
\end{tabular}




\begin{tabular}{|c|c|c|c|c|c|c|c|c|c|}
\hline 12. & $\begin{array}{l}\text { Technology provided is not } \\
\text { adequate and timely (-) }\end{array}$ & 4.20 & 34 & 33 & 17 & 65 & 71 & 69.90 & XV \\
\hline 13. & $\begin{array}{l}\text { Application of sulphur } \\
\text { increases yield and oil } \\
\text { content in Soybean seeds (+) }\end{array}$ & 3.40 & 108 & 112 & 0 & 0 & 0 & 85.63 & III \\
\hline 14. & $\begin{array}{l}\text { Recommended Soybean } \\
\text { cultivation practices do not } \\
\text { significantly contribute to } \\
\text { increase soybean production } \\
(-)\end{array}$ & 4.44 & 12 & 19 & 27 & 66 & 96 & 79.54 & $X$ \\
\hline 15. & $\begin{array}{l}\text { Recommended Soybean } \\
\text { cultivation practices } \\
\text { advocated are technically } \\
\text { (e.g. mechanical weeder) } \\
\text { sound (+) }\end{array}$ & 3.56 & 74 & 101 & 33 & 10 & 2 & 82.09 & VI \\
\hline 16. & $\begin{array}{l}\text { Short duration training } \\
\text { organized during the } \\
\text { programme is not sufficient } \\
\text { to perform agricultural } \\
\text { operation successfully in } \\
\text { Soybean cultivation } \\
(-)\end{array}$ & 3.50 & 14 & 22 & 12 & 93 & 79 & 78.27 & XI \\
\hline 17. & $\begin{array}{l}\text { The risk of cultivation is } \\
\text { minimized with the adoption } \\
\text { of improved production } \\
\text { technology }(+)\end{array}$ & 2.12 & 76 & 106 & 10 & 22 & 6 & 80.36 & IX \\
\hline 18. & $\begin{array}{l}\text { Seed and soil treatment are } \\
\text { not beneficial to farmers (-) }\end{array}$ & 3.68 & 11 & 50 & 12 & 76 & 71 & 72.45 & XIV \\
\hline
\end{tabular}

SA = Strongly Agree, A = Agree, UD= Undecided, Disagree, SDA= Strongly Disagree

The favourable results so obtained "I prefer HYVs to local variety as it gives high production than local variety", "Recommended field preparation increases production and reduces cost of cultivation", "Application of sulphur increases yield and oil content in soybean seeds", "The soybean cultivation practices have improved social status of the farmers", and might be due to the facts that various extension activities like demonstrations, trainings, field days etc. are frequently organized by the KVK scientists in villages, which might have helped in convincing farmers about soybean technology, which has resulted in changing the attitude of farmers towards recommended soybean cultivation practices. The data given in table also reveal that farmers have favourable attitude towards other statements of recommended soybean cultivation practices like "HYVs have good storage quality so can be stored for a longer period of time", "Recommended Soybean cultivation practices advocated are technically (e.g. mechanical weeder) sound", "Recommended soybean cultivation practices require regular contact with extension Workers", Recommended soybean cultivation practices are cheap, and trust worthy, "The risk of cultivation is minimized with the adoption of improved production technology" "Recommended soybean cultivation practices 
do not significantly contribute to increase soybean production" "Short duration training organized during the programme is not sufficient to perform agricultural operation successfully in soybean cultivation" "I have not preferred recommended dose of NPK and pesticides and "Technology advocated is not according to farmers' resources and their needs" with score $82.45,82.09,81.54,80.63$, 80.36, 79.54, 78.27, 76.90, and 75.18 MPS, respectively. The reason is because these aspects/practices minimized the risk of pest and diseases. It means technology provided to farmers on soybean crop bring significant improvement in farmers' income where VEWs and other agriculture officials are helpful to farmers. The statements which indicate moderate attitude of farmers towards recommended soybean cultivation practices like "Seed and soil treatment are not beneficial to farmers" "Technology provided is not adequate and timely, "HYVs are more expensive than local variety as they have higher seed cost" had scoring 64.90,59.72, and 56.72 MPS, respectively.

The farmers expressed least favourable attitude towards statements of recommended soybean cultivation practices like "Recommended Soybean cultivation practices are not suitable for uneducated farmers" Soil testing is not necessary for application of recommended quantity of chemical fertilizers", owing to the low per cent score 57.00, and 53.00 MPS, respectively. This might be due to the facts that most of farmers have low knowledge and are unaware about the benefits of these aspects and faced more constraints in use of these practices like some time main crop burned by herbicide used for weed control or other chemicals used for soil or seed treatment. The results regarding statement wise attitude of farmers towards recommended soybean cultivation practices were also presented diagrammatically.
The findings of the study were in conformity with the findings of Tiwari et al., (2002), Prasad (2011), Prabhakar et al., (2011), Singh et al., (2014), and Kumawat (2015).

More than half of the respondents had medium level of attitude about recommended soybean cultivation practices. Regarding aspect wise attitude, most favourable attitude was found relating to "I prefer HYVs to local variety as it give high production than local variety", on the other hand, the least favourable attitude was found with regard to "Soil testing is not necessary for application of recommended quantity of chemical fertilizers".

\section{References}

Jha, P.N. 1968, A Critical Analysis of Factor Associated with Communication Fidelity with response to high yielding Verities programme. Ph.D. Thesis (Unpublished). Division of Ext. Edu., IARI, New Delhi.

Jha, P.N., Kulhari, V.S. and Shaktawat, G.S. 1978, A Scale to Measure peoples attitude towards family planning. Ind. Journal Psychology. 45 (3), 249-257.

Kaur, M.S. and Singh, Y.P. 1968. A Scale to Measure farmers' attitude towards Artificial Insemination., Ind. Jour. of Ext.Edu.

Kumawat, R. 2015. Knowledge and attitude of farmers towards recommended production technology of rapeseed and mustard crop in district Tonk (Rajasthan)." M.Sc. (Ag.) Thesis (Unpub.), SKNAU, Jobner CampusJobner.

Parsad, 2011. Impact of Front line demonstrations on knowledge, attitude and adoption of recommended production technology of mustard cultivation by the farmers in Bhartpur 
district of Rajasthan" M.Sc. Thesis, SKRAU, Bikaner, Campus-Jobner.

Prabhakar, P. K.; Ansari, M. N. and Sinha, K. K. 2011 Attitude of farmers towards rapeseed and mustard production technology as a result of front line demonstration". $J . \quad$ of Interacademicia, 15 (3):467-473.

Singh, R., Hansra B.S., Singh R. and Ramesh Chand 2014. Knowledge and adoption level of farmers of Haryana about scientific wheat cultivation practices" Ind. J. Ag. Res., 48 (1): 52 -56.
Singh, R.P., and Singh, K.N. 1968, Attitude of farm people towards chemical fertilizer. Ind. Jour. of Ext.Edu. 4 (1\&2), 49-53.

Thrustone, L.L. 1946. The measurement of attitude". American Journal of society, Chicago University, pp.39-40.

Tiwari, R.K., Chauhan, J. and Sharma, P.N. 2002. Acquaintance and attitude of tribal farmers towards modern rice production technology". Ind. Res. J. Extn. Edu. 2 (1): 111-113.

\section{How to cite this article:}

Surendra Kumar, N.K. Sharma, H.S. Bunkar and Ramdhan Gashwa. 2018. Develop Attitude Scale and Measure the Attitude of Farmers towards Recommended Soybean Cultivation Practices. Int.J.Curr.Microbiol.App.Sci. 7(03): 3484-3490. doi: https://doi.org/10.20546/ijcmas.2018.703.400 